\title{
РЕГЕНЕРАТИВНА МОДУЛЯЦІЯ ВУГЛЕВОДНОГО ОБМІНУ ТА ІНКРЕТОРНОЇ АКТИВНОСТІ $\beta$-КЛІТИН ПІДШЛУНКОВОЇ ЗАЛОЗИ
}

\section{Регенеративна модуляція вуглеводного обміну та інкреторної активності $\beta$-клітин підшлункової залози}

Е. В. Федорова ${ }^{1}$, Г. Й. Лавренчук², Я. О. Мірошников ${ }^{1}$, А. І. Довгалюк ${ }^{3}$, І. М. Кліщ ${ }^{3}$

ТОВ «Медичний центр «/нститут сімейної медицини плюс»» ${ }^{1}$

ДУ «Національний науковий центр радіаційноі медицини НАМН України»²

Тернопільський національний медичний університет імені І. Я. Горбачевського МОЗ України ${ }^{3}$

Резюме. Гострота проблеми порушень вуглеводного обміну - метаболічного синдрому і цукрового діабету - не потребує доказів. Дані епідеміології цих захворювань, інвалідизації та передчасної смертності дуже красномовні. Водночас, залишаються актуальними питання раціональної компенсації порушень вуглеводного обміну і нерозривно пов'язане з ними відновлення інкреторної активності підшлункової залози.

Мета дослідження - з'ясувати ефрективність лікування і проаналізувати зміст глікозильованого гемоглобіну (HbA1c) і C-пептиду у хворих на цукровий діабет 2 типу, які до госпіталізації отримували традиційну цукрознижувальну терапію і перебували під диспансерним наглядом за місцем проживання.

Матеріали і методи. У клініці «МЦ «/нституm сімейної медицини плюс» пацієнтам було проведено комплексне лікування, яке включало: корекцію цукрознижувальної терапії, детоксикацію, патогенетичну фрізіотерапію і регенеративну терапію: внутрішньовенну інфузію мультипотентних мезенхімальних стовбурових клітин і підшкірні ін'єкції екстракту плаценти. До та після лікування проводили комплексне обстеження, що включало в себе, окрім загальноклінічних і біохімічних аналізів, дослідження панелі вуглеводного обміну із визначенням HbA1c і С-пептиду.

Результати. Лікування цукрового діабету 2 типу мезенхімальними стовбуровими клітинами дозволяє не тільки підвищити ефрективність лікування традиційними засобами та методиками, але часом і повністю від них відмовитися. Стовбурові клітини відновлюють чутливість тканин і клітин організму до діі інсуліну, значно покращують фрункцію підшлункової залози, що приводить до нормалізації рівня цукру в крові.
Regenerative modulation of carbohydrate metabolism and incretory activity of $\beta$-cells of the pancreas

E. V. Fedorova ${ }^{1}$, G. Y. Lavrenchuk ${ }^{2}$, Ya. O. Miroshnykov' ${ }^{1}$, A. I. Dovgalyuk ${ }^{3}$, I. M. Klishch ${ }^{3}$ Ltd."MC" Institute of Family Medicine Plus"1 National Scientific Center of Radiation Medicine of the National Academy of Medical Sciences of Ukraine ${ }^{2}$ I. Horbachevsky Ternopil National Medical University ${ }^{3}$

$$
\text { e-mail: eleonoraf115@gmail.com }
$$

Summary. The acuteness of the problem of carbohydrate metabolism disorders - metabolic syndrome and diabetes mellitus - does not require evidence. Epidemiological data on these diseases, disability and premature mortality are very eloquent. Simultaneously, the issues of rational compensation of carbohydrate metabolism disorders and the inextricably linked with it restoration of the incretory activity of the pancreas remain relevant.

The aim of the study - in order to determine the effectiveness of treatment, the content of glycosylated hemoglobin (HbA1C) and C-peptide was analyzed in patients with type 2 diabetes mellitus who received traditional antidiabetic therapy before admission to the clinic and were under dispensary supervision at the place of residence.

Materials and Methods. At the clinic "MC" Institute of Family Medicine Plus" patients underwent comprehensive treatment, which included: correction of antidiabetic therapy, detoxification, pathogenetic physiotherapy and regenerative therapy: intravenous infusion of multipotent mesenchymal stem cells and subcutaneous injections of placenta extract. Before and after treatment, a comprehensive examination was performed, which included, in addition to general clinical and biochemical analyzes, a study of the carbohydrate metabolism panel, with the determination of HbA1c and C-peptide.

Results. Using of mesenchymal stem cells can not only increase the effectiveness of the type 2 diabetes treatment with traditional means and techniques, but sometimes allows completely abandon them. Stem cells restore the sensitivity of human tissues and cells to insulin action; significantly improve the function of the pancreas, which leads to the normalization of blood sugar levels. 
Висновки. Отримані дані після повторного обстеження хворих, проведеного через 3 місяці після лікування, свідчать про перспективність застосування клітинних технологій як патогенетичного методу компенсації вуглеводного обміну і запобігання ускладнень цукрового діабету.

Ключові слова: цукровий діабет 2 типу; глікозильований гемоглобін; С-пептид; клітинна терапія.

\section{ВСТУП}

Цукровий діабет (ЦД) є складним поліфакторним захворюванням, у патогенезі якого провідну роль відіграють інсулінорезистентність, гіперглікемія та хронічний запальний процес. Це призводить до порушення усіх типів обміну речовин та розладів у фрункціонуванні багатьох систем органів, що зумовлює розвиток численних ускладнень діабету.

Незважаючи на багаторічне вивчення ЦД і пошук нових методів його лікування, це захворювання залишається великою проблемою сучасної медицини. 3 кожним роком кількість хворих, які страждають від ЦД, збільшується. Якщо в 2014 р. у світі на ЦД хворіло 387 млн чоловік, то до 2035 р. кількість хворих може досягти 592 млн [1-4]. Найбільша кількість людей з діабетом віком від 40 до 59 років. 179 млн людей з діабетом не діагностовані. Кожні сім секунд у світі помирає одна людина від ЦД.

Успіх у розробці нових методів лікування ЦД визначається розумінням патогенезу даного захворювання. У даний час основною причиною гіперглікемії при цукровому діабеті 1 типу вважається десріцит $\beta$-клітин острівців Лангерганса або їх ушкодження, що призводить до низької концентрації інсуліну і (або) порушень його фрункціонування. Вивчення шляхів регенерації $\beta$-клітин підшлункової залози важливо для пошуку нових підходів при лікуванні діабету 1 і 2 типів. Ключовим завданням будь-якої терапії інсулінозалежного діабету $€$ збільшення кількості $\beta$-клітин підшлункової залози. На сьогодні описано кілька шляхів вирішення цього завдання з високим терапевтичним потенціалом.

Отже, залишаються актуальними питання раціональної компенсації вуглеводного обміну і відновлення інкреторної активності підшлункової залози, які нерозривно пов'язані з ними.

Загальновизнаним показником компенсації вуглеводного обміну є глікозильований гемоглобін (HbA1c). Це показник як адекватності цукрознижувальної терапії, так і комплаєнтності пацієнта [5, 6]. С-пептид - показник інкреторної активності острівців Лангерганса, який майже не залежить від традиційних фрармакологічних впливів, тобто арсенал впливу лікаря на цей показник дуже обмежений $[7,8]$.
Conclusions. The data obtained after re-examination of patients, conducted 3 months after treatment, indicate the prospects for the using of cell therapy as a pathogenetic method of compensating for carbohydrate metabolism disorders and preventing complications of diabetes.

Key words: type 2 diabetes mellitus; glycosylated hemoglobin; C-peptide; cell therapy.

Ось чому саме ці показники вуглеводного обміну стали основними критеріями оцінки ефеектвності досліджуваного методу.

\section{МАТЕРІАЛИ I МЕТОДИ}

Під нашим спостереженням у клініці «МЦ «Інститут сімейної медицини плюс» знаходилося 20 пацієнтів з МС і ЦД 2 типу, в тому числі 11 з них отримували інсулінотерапію. Середній вікхворих становив 52 роки. Середня тривалість захворювання була 5,3 року. Пацієнти протягом усього захворювання до надходження в клініку отримували традиційну цукрознижувальну терапію і перебували під диспансерним наглядом за місцем проживання. Водночас, у 13 пацієнтів ЦД був у стані декомпенсації: HbA1c>7; а у 3 хворих - у стадії субкомпенсації: НbA1c>6.

У клініці «МЦ «Інститут сімейної медицини плюс» пацієнтам було проведено комплексне лікування, а саме:

1. Корекцію цукрознижувальної терапії (біогуаніди, інгібітори дПП-4, інгібітори натрійзалежного контранспортера глюкози, препарати сульсоннілсечовини).

2. Детоксикацію у вигляді інфузійної терапії та реоксигенації 3 моделюванням перебування на високогір'ї [9].

3. Патогенетичну срізіотерапію з метою боротьби з нейропатією і активації власних регенеративних резервів (ударно-хвильова терапія проблемних зон [10]).

4. Регенеративну терапію: внутрішньовенна інфрузія мультипотентних мезенхімальних стовбурових клітин (ММСК) з розрахунку 1 млн клітин на 1 кг маси тіла та підшкірні ін'єкції екстракту плаценти.

До і після лікування проводили комплексне обстеження, що включало в себе, окрім загальноклінічних і біохімічних аналізів, дослідження панелі вуглеводного обміну 3 визначенням $\mathrm{HbA1c}$ i С-пептиду.

Статистичну обробку даних здійснювали за допомогою стандартних програм на персональному комп'ютері 3 використанням пакета програм STATISTICA (версія 10). Розраховували параметри нормального розподілу: середні вибірки (M), середнє квадратичне відхилення (S), середню по- 
милку середньої арисрметичної (m). Достовірність відмінностей між двома незалежними групами визначали за критерієм Стьюдента, різницю вважали достовірною при $\mathrm{p} \leq 0,05$.

\section{РЕЗУЛЬТАТИ Й ОБГОВОРЕННЯ}

Після проведення всіх процедур та комплексного обстеження було встановлено зниження значення C-пептиду у 4-х (20 \%) з 20-ти обстежуваних, в одного (5 \%) показник був підвищений; у 15-ти (75 \%) він перебував у межах норми з тенденцією до зниження. Контрольне обстеження, проведене через 3 місяці після закінчення лікування, зафіксувало підйом вмісту С-пептиду в 17-ти (85 \%) 3 20ти пацієнтів, лише у 3-х (15 \%) показник знизився, причому в одного із 3-х вміст С-пептиду був спочатку підвищеним. Дані динаміки С-пептиду наведено в таблиці 1.

Таблиця 1. Динаміка вмісту С-пептиду в пацієнтів із ЦД 2 типу

\begin{tabular}{c|c|c}
\hline $\begin{array}{c}\text { Норма, } \\
\text { нг/мл }\end{array}$ & $\begin{array}{c}\text { Показник,нг/мл, до лі- } \\
\text { кування }(\mathrm{M} \pm \mathrm{m})(\mathrm{n}=20)\end{array}$ & $\begin{array}{c}\text { Показник, нг/мл, } \\
\text { після лікування } \\
(\mathrm{M} \pm \mathrm{m})(\mathrm{n}=20)\end{array}$ \\
\hline $0,81-3,85$ & $1,47 \pm 0,17$ & $2,4 \pm 0,21^{*}$ \\
\hline
\end{tabular}

Примітка. ${ }^{*}$ - p $\leq 0,001$, різниця статистично достовірна порівняно 3 показником до лікування.

Проаналізувавши отримані результати, ми вважаємо, що клітинна модуляція є методом вибору в корекції інкреторної фрункції підшлункової залози, причому як у бік підвищення резервів інсуліну, так i, при необхідності, зниження продукції патологічного проінсуліну; її дію ми пов'язуємо як з прямим впливом на активність острівців Лангерганса, так і з системним імуномодулюючим впливом на синтез антитіл до острівців та інсуліну [8].

Динаміка HbA1c, наведена в таблиці 2, демонструє достовірне зниження показника у 70 \% обстежуваних пацієнтів, причому у 10-ти з них (50 \%) була досягнута повна компенсація або субкомпенсація (HbA1c<7).

Таблиця 2. Динаміка вмісту HbA1c у пацієнтів із ЦД 2 типу

\begin{tabular}{c|c|c}
\hline НbA1c, \%, & НbA1c, \%, & НbA1c, \%, \\
$\begin{array}{c}\text { контрольна група } \\
(\mathrm{M} \pm \mathrm{m})\end{array}$ & $\begin{array}{c}\text { до лікування } \\
(\mathrm{M} \pm \mathrm{m})\end{array}$ & $\begin{array}{c}\text { після лікування } \\
(\mathrm{M} \pm \mathrm{m})\end{array}$ \\
\hline $\mathrm{n}=120)$ & $(\mathrm{n}=20)$ & $(\mathrm{n}=20)$ \\
\hline $7,04 \pm 1,8$ & $7,73 \pm 0,34$ & $7,03 \pm 0,28^{\star}$ \\
\hline
\end{tabular}

Примітка. * - p $\leq 0,05$, різниця статистично достовірна порівняно 3 показником до лікування.

СПИСОК ЛІТЕРАТУРИ

1. Zheng Y. Global aetiology and epidemiology of type 2 diabetes mellitus and its complications / Y. Zheng, S. H. Ley,
3 11-ти пацієнтів, які приймали інсулін, 7 повністю відмовилися від інсулінотерапії, а 4 знизили дозу інсуліну в середньому на 30-40 \%. Лікування цукрового діабету 2 типу стовбуровими клітинами дозволяє не тільки підвищити ефективність лікування традиційними засобами та методиками, але часом і повністю від них відмовитися. Стовбурові клітини відновлюють чутливість тканин і клітин організму до дії інсуліну, значно покращують функцію підшлункової залози, що приводить до нормалізації рівня цукру в крові.

Отримані дані, на наш погляд, свідчать про перспективність застосування клітинних технологій як патогенетичного методу компенсації порушень вуглеводного обміну і запобігання ускладнень цукрового діабету.

Отже, у дослідженні ми постарались отримати відповіді на питання: як працює стовбурова клітина при цукровому діабеті? Виявилось, що діє вона багатосторонньо. Перший аспект - стимуляція та підтримання підшлункової залози, що працює на знос; другий - відновлення чутливості рецепторів клітин до дії інсуліну; третій - вплив у якості ангіопротектора, що захищає судинні стінки від шкідливого впливу інсуліну і глюкози; четвертий аспект надання імуностимулюючого ефекту. Таким чином, вплив комплексний.

Коротко зазначимо, що ММСК здатні мігрувати до травмованих/уражених ділянок, впливаючи на регенерацію тканин як завдяки секреції трофрічних чинників, так і паракринних медіаторів; мають імуносупресивні властивості завдяки цитокінам та імуномодулюючим речовинам, що виділяють. Надходження клітин до тканин-мішеней може бути здійснено шляхом внутрішньоартеріальних ін'єкцій $[11,12]$.

\section{вИСновкИ}

1. Застосування клітинної терапії у комплексному лікуванні цукрового діабету забезпечує повну (50 \%) або часткову компенсацію (20 \%), про що свідчить достовірна позитивна динаміка $\mathrm{HbA1c.}$

2. Використання мультипотентних мезенхімальних стовбурових клітин та екстракту плаценти дозволяє позитивно впливати на інкреторну функцію підшлункової залози у 85 \% пацієнтів із ЦД.

3. Застосування клітинної терапії дозволяє підвищити ефективність лікування і запобігання ускладнень цукрового діабету, а в деяких випадках - відмовитися від інсулінотерапії, і може бути перспективним патогенетичним методом корекції вуглеводного обміну.

F. B. Hu // Nat. Rev. Endocrinol. - 2018. - No. 14 (2). - P. 8898. - Access mode : https://doi.org/10.1038/nrendo.2017.151. 
2. Балаболкин М. И. Сахарный диабет: как сохранить полноценную жизнь. - М. : Медицина, 2006. - 210 с.

3. Основні показники діяльності ендокринологічної служби України за 2008 рік / за ред. М. Д. Тронько, А. Д. Чорноброва. - К. : Інститут ендокринології та обміну речовин ім. В. П. Комісаренка АМН України, 2009. $-33 \mathrm{c}$.

4. American Diabetes Association. Standards of medical care in diabetes // Diabetes Care. - 2011. - Vol. 34 (Suppl. 1). - P. 11-61.

5. Балаболкин М.И.Частота возникновения макроангиопатий при сахарном диабете 1 и 2 типа / М. И. Балаболкин Г. Х. Чурмантаев // Хирургические заболевания и сахарный диабет. - М., 2007. - С.12 - 22.

6. Клинические рекомендации по диагностике и лечению синдрома диабетической стопы / Г. Р. Галстян, А. Ю. Токмакова, Д. Н. Егорова // Раны и раневые инфекции. Журнал имени проф. Б.М. Костючёнка. - 2015. - № 2(3). - С. 63-83. https://doi.org/10.17650/2408-96132015-2-3-63-83

7. Leighton E. A practical review of C-peptide testing in diabetes / E. Leighton, C. A. Sainsbury, G. C. Jones // Diabetes Ther. - 2017. - Vol. 8 (3). - P. 475-487. - Access

\section{REFERENCES}

1. Zheng $\mathrm{Y}$, Ley $\mathrm{SH}$, Hu FB. Global aetiology and epidemiology of type 2 diabetes mellitus and its complications. Nat Rev Endocrinol. 2018;14(2): 88-98. Available from: https://doi.org/10.1038/nrendo.2017.151.

2. Balabolkin MI. Diabetes mellitus: how to maintain a full life. [Сахарный диабет: как сохранить полноценную жизнь] Moscow: Meditsina; 2006. Russian.

3. Tronko MD, Chornobrova AD, Eds. The main indicators of the endocrinological service of Ukraine for 2008. [Основні показники діяльності ендокринологічлної служби України за 2008 рік] Kyiv: V.P. Komisarenko Institute of Endocrinology and Metabolism of the Academy of Medical Sciences of Ukraine; 2009. Ukrainian.

4. American Diabetes Association. Standards of medical care in diabetes. Diabetes Care. 2011;34(Suppl. 1): 11-61.

5. Balabolkin MI, Churmantaev GKh. [Frequency of occurrence of macroangiopathies in diabetes mellitus type 1 and 2]. Khirur zabol i sakharn diab. Moscow: Meditsina; 2007. Russian.

6. Galstyan GR, Tokmakova AYu, Egorova DN, Mitish VA, Paskhalova YS, Antsiferov MB, et al. [Clinical guidelines for diagnosis and treatment of diabetic foot syndrome]. Rany i ranev infekts. Prof. B.M. Kostyuchenok zhurn. 2015;2(3): mode : https://doi.org/10.1007/s13300-017-0265-4 Epub 2017 May 8. PMID: 28484968; PMCID: PMC5446389.

8. Дедов И. И. Персонализованная терапия сахарного диабета. Путь от болезни к больному / И. И. Дедов М. В. Шестакова // Терапевтический архив. - 2014. - 10. C. 4-9.

9. Буравкова Л. Б. Клеточные эфффекты краткосрочной гипоксии и реоксигинации / Л. Б. Буравкова, В. Б. Туровецкий // Материалы X Международного симпозиума «Эколого-физиологические проблемы адаптации». - М., 2001. -C. 121-123.

10. Аксенов П. В. Низкоэнергетическая ударно-волновая терапия в коррекции эректильной дисорункции : обзор литературы / П. В. Аксенов // Здоровье мужчины. - 2014. - № 1. - C. 58 - 67.

11. Caplan A.I. Adult mesenchymal stem cells for tissue engineering versus regenerative medicine / A. I. Caplan // J. Cell Physiol. - 2007. - Vol. 213 (2). - P. 341-347.

12. Shin L. Human mesenchymal stem cell grafts enhance normal and impaired wound healing by recruiting existing endogenous tissue stem/progenitor cells / L. Shin, D. A. Peterson // Stem Cells Transl. Med. - 2013. Vol. 2 (1). - P. 33-42.

63-83. Available from: https://doi.org/10.17650/2408-96132015-2-3-63-83. Russian.

7. Leighton E, Sainsbury CA, Jones GC. A practical review of C-peptide testing in diabetes. Diabetes Ther. 2017;8(3): 475-87. Available from: https://doi.org10.1007/ s13300-017-0265-4 Epub 2017 May 8. PMID: 28484968; PMCID: PMC5446389.

8. Dedov II, Shestakova MV. [Personalized therapy of diabetes mellitus. The path from illness to sick]. Terapevt arkhiv. 2014;10: 4-9. Russian.

9. Buravkova L. B., Turovetsky V. B. Cellular effects of short-term hypoxia and reoxygenation. Materials of the $X$ International Symposium "Ecological and physiological problems of adaptation." Moscow; 2001. Russian.

10. Aksenov PV. [Low-energy shock wave therapy in the correction of erectile dysfunction (literature review)]. Zdorov muzhch. 2014;1: 58-67. Russian.

11. Caplan Al. Adult mesenchymal stem cells for tissue engineering versus regenerative medicine. J Cell Physiol. 2007;213(2): 341-7.

12. Shin L, Peterson DA. Human mesenchymal stem cell grafts enhance normal and impaired wound healing by recruiting existing endogenous tissue stem/progenitor cells. Stem Cells Transl Med. 2013;2(1): 33-42. 